\title{
Problemshed or Watershed? Participatory Modeling towards IWRM in North Ghana
}

\author{
William's Daré ${ }^{1,2, *(\mathbb{D})}$, Jean-Philippe Venot ${ }^{3,4}$, Christophe Le Page ${ }^{1,2}$ (D) and Aaron Aduna 5 \\ CIRAD, UPR GREEN, 34398 Montpellier, France; christophe.le_page@cirad.fr \\ GREEN, CIRAD, Univ Montpellier, 34398 Montpellier, France \\ UMR G-EAU, IRD, University of Montpellier, 34196 Montpellier, France; jean-philippe.venot@ird.fr \\ Water Resources Management Group, Wageningen University, 6700-PB Wageningen, The Netherlands \\ White Volta Basin Board, Water Resources Commission, PO Box 489, Bolgatanga, Ghana; \\ aaronaduna@gmail.com \\ * Correspondence: williams.dare@cirad.fr; Tel.: +33-(0)4-9962-4890
}

Received: 13 April 2018; Accepted: 29 May 2018; Published: 2 June 2018

\begin{abstract}
This paper is a reflexive analysis of a three-year participatory water research project conducted in the Upper East Region (UER) of Ghana, whose explicit objective was to initiate a multi-level dialogue to support the national Integrated Water Resources Management (IWRM) policy framework. The transdisciplinary team adopted the Companion Modeling approach (ComMod), using role-playing games and a computerized agent-based model to support the identification of a problemshed centered on issues of river bank cultivation, erosion, and flooding, and initiate a multi-level dialogue on ways that this problemshed could be tackled. On the basis of this experience, we identify three key criteria for transdisciplinary research to support innovative water governance: (1) the iterative adaptation of tools and facilitation techniques based on feedback from participants; (2) a common understanding of the objectives pursued and the approach used among researchers, who need to explicit their posture, and crucially; (3) the co-identification of a problemshed that diverse stakeholders are interested in tackling. Finally, we argue that the context in which research is funded and conducted in the development sector constitutes a challenge for researchers to be "participants like any other" in the projects they coordinate, which constitutes a barrier to true transdisciplinarity.
\end{abstract}

Keywords: water resources; companion modeling; role-playing game; agent-based model; Sub-Saharan Africa

\section{Introduction}

Over the last two decades, Integrated Water Resources Management (IWRM) has imposed itself as the primary governance framework for water managers worldwide [1]. According to its main global advocate, the Global Water Partnership (GWP), IWRM rests on four guiding principles: water is a finite and vulnerable resource that is best managed along the hydrological boundaries of river basins; water development and management should be based on participatory approaches involving stakeholders at multiple levels of decision-making; women play a central role in the provision, management, and safeguarding of water; and water has an economic value, and should be managed as an economic good [2]. Today, more than two thirds of all countries in the world appear to have embraced these principles through the development of national IWRM plans [3].

Despite such prominence at international and national levels, IWRM has faced mounting criticism among scholars and practitioners alike, who have highlighted the difficulties that exist to implement these principles in practice, notably in developing countries [4]. The idea of integration is not really questioned as such, although a recent comparative analysis of IWRM implementation shows that 
trade-offs exist between functional, societal, and institutional integration and are seldom accounted for [5], and implementation challenges are generally attributed to two main factors. First, the rigidity with which the four GWP guiding principles have been erected in "good practices" including the focus on the river basin as the sole adapted scale for water management [6,7], and a skewed attention to issues of demand management and effective allocation on the basis of market principles, even though most small-scale water users in developing countries are still primarily interested in improved water access [8]. Second, a lack of political will from national water elites to follow IWRM principles that are opposed to their centralized vision of regulatory river basin management [9].

In this paper, we discuss IWRM through another angle, and engage with the issue of cross-scale integration and participation that underpins this governance model. We do so through a critical reflection on a transdisciplinary research project that we designed, implemented, and built on two bodies of literature seldom used in conjunction: the social science literature on participation and multi-stakeholder platforms, and the modeling literature.

Scholars have long described the challenges faced by participatory approaches to, for instance, address power imbalances [10,11], avoid the misrepresentation of actors [12], or ensure that these actors have similar opportunities to voice their interests when it comes to natural resources management [13]. To institutionalize participation, some scholars consider multi-stakeholder platforms (MSP), as "decision-making bodies (voluntary or statutory) comprising different stakeholders who perceive the same resource management problem, realize their interdependence for solving it, and come together to agree on action strategies for solving the problem" [14] (p. 244), the logical companion of IWRM [15]. However, even if they deal with the issue of interconnecting multiple uses and users, as highlighted by Faysse [16], MSPs have often been implemented in contexts characterized by social inequities where (the improvement of) communication processes was not enough to solve the problems that participants wanted to address. As such, Faysse proposed to consider MSP as processes rather than practical solving tools [16]. In turn, models and modeling activities have been shown to offer opportunities to go beyond improved communication towards the identification of practical solutions, for instance in terms of integrated environmental assessment and management [17], or address the multiple dimensions of IWRM [18]. Since they can tackle the complexity of water and more broadly natural resources management by accommodating multiple issues, values, scales, and uncertainty considerations, models are "tools that integrate" [19] and can be used to support MSP. As with any participatory approach, when models are developed in direct interaction with stakeholders and researchers who belong to multiple sectors and different decision-making levels, there is a need to strategically organize the interactions between participants [20] so that they all feel they have opportunities to voice their views and hence contribute to the development of the modeling process. Done in such a way, and because they can account for multiple bodies of knowledge, participatory modeling not only improves models' outputs, it can also support social learning cycles that have long been seen as a key element of IWRM and adaptive water resources governance frameworks [21-23].

Drawing from these insights into MSP and modeling methods, this article is a critical reflection on transdisciplinary water research and the extent to which it can indeed support multi-level water governance. We reflect on a three-year action-research project that aimed at understanding and supporting IWRM policy-making and implementation in Ghana (see https://waterandfood.org/ river-basins / volta/ for further information) through the establishment of a multi-level dialogue and institutional arrangements using the Companion Modeling approach (ComMod). The Implementation of Integrated Water Resources Management principles was at its infancy at the start of the process, and largely took place through development projects implemented by a diversity of actors. This made it difficult for the Water Resources Commission and more specifically the White Volta Basin Board, who were partners in the research and in charge of IWRM implementation, to play their integration role, notably in the face of floods and soil degradation that they considered most acute and caused by, but also detrimental to, local livelihoods. 
In contrast with the classic approach that sees researchers identify a problem a priori (beyond the generally framed challenge of "implementing IWRM"), and then adopt a participatory approach to find and discuss potential solutions to this problem collectively, the primary result of the research is the very collective identification of a shared "problemshed", which, in line with Mollinga [24], we define as a loose issue-and-actor-network that is bounded in space. We argue that this problemshed could lay the basis for the practical "translation" of IWRM in some parts of the Upper East Region (UER) of Ghana. How this translation happens practically (e.g., the identification and implementation of "solutions" to the problem) still remains to be seen, and largely hinges on the long-term sustainability of the process that we contributed to initiate.

The structure of the paper reflects our transdisciplinary approach: rather than describing the problemshed as a given at the start of the paper, we describe and critically reflect on the participatory process first, and then sketch the "problemshed", whose identification constitutes the main outcome of the participatory process. The following section briefly discusses the water governance framework of Ghana and the case study area. We then describe the participatory approach that was designed and implemented over a three-year period (Section 3), describing the objectives, participants, and tools used in each activity. The discussion in Section 4 then reflects on the participatory process and investigates the adaptation and adjustments of the tools that were designed, the facilitation techniques and knowledge exchange dynamics, as well as the role that different team members had in shaping the process, and highlights how this served the identification of a shared problemshed around which collective action for innovative water governance could take place. The conclusion attempts to identify key elements for transdisciplinary research to support innovative water governance in a development context, and links our specific experience to the broader literature on social learning and the role of researchers in participatory approaches.

\section{Case Study Area in the Ghana Water Governance Framework}

\subsection{The Ghana Water Governance Context}

In Ghana, similar to in many other countries of the world, the control and management of water has long been seen as a crucial tool for agricultural and broader economic development. The hydropower Akosombo Dam, which was completed in 1965, has for instance created one of the largest human-made lakes of the world, and supports intensive agricultural (irrigation and fisheries) and industrial activities.

Water resources development has come hand in hand with institutional and political reforms, which, from the 1990s onwards have been informed by IWRM principles. In Ghana, IWRM principles first acquired an organizational reality in 1996, with the establishment of the Water Resource Commission (WRC) by the Parliament Act 522 of 1996. The mandate of the WRC is "to regulate and manage the sustainable utilization of water resources and to coordinate related policies [... ] for the socio-economic development of Ghana". Further institutionalization of IWRM took place with the enactment of the 2007 National Water Policy (NWP) instituting the Ministry of Water Resources, Works, and Housing (MWRWH) as the lead governing institution responsible for water. The policy also promoted a nested approach to water governance along the decentralized state system operating at national, regional, and district levels [25].

Despite such institutional development and attempts at integration, responsibilities over water remain scattered across multiple institutional jurisdictions. The MWRWH for instance is mostly focused on drinking water supplies, while other sector ministries deal with water issues in relation to irrigation (Ghana Irrigation Development Authority and Ministry of Food and Agriculture), fisheries (Ministry of Fisheries), hydropower (Volta River Authority and Ministry of Energy), and water transportation (Ministry of Harbors and Railways). The WRC is made up of representatives from different ministries and governmental agencies, civil society, private companies, and traditional authorities (one of which, 
at least, should be a woman, www.wrc-gh.org), and marks a nascent horizontal integration (notably at national and regional levels); however, vertical integration across levels remains a challenge.

Indeed, the WRC, is only made up of national level representatives who are generally based in Accra, thus providing little space for direct vertical integration. Information from regional and district levels is meant to be passed on through the respective reporting lines of the organizations represented in the commission, but this rarely happens. Even within the WRC, formal vertical integration appears to be weak. Indeed, between 2004-2012, five river basin boards have been set up under the WRC (Densu, White Volta, Ankobra, Pra, and Tano), but the WRC itself does not count any representatives from these boards, which have a consultative and advisory role as it relates to the management of water in their respective basins. The main form of interactions existing between these boards and the WRC is one of hierarchy, whereby basin officers (in charge of facilitating the activities of the boards) report to the chief executive of the WRC.

Zooming on the White Volta Basin Board (WVBB), which was officially established in 2006 to oversee water development and management in the largest river basin of the country, reveals a geographically biased representation. Despite its name, most of the representatives sitting on the board come from the Upper East Region (UER) of Ghana, which represents less than 20\% of the total area of the White Volta Basin in Ghana (see Figure 1). This is largely linked to the WVBB secretariat being physically located in Bolgatanga, the regional capital of the UER, and that the basin officer has preferential professional relationships with the administrative and traditional authorities in this region. Each district assembly of the Upper East Region is a statutory member of the board (together with regional level traditional authorities, civil society members, and the regional offices of different sector ministries), while the district assemblies of the other regions located in the basin are not all represented. Further, for several years, the board has only provided limited opportunities for integration and coordination, as it first met six years after its creation.

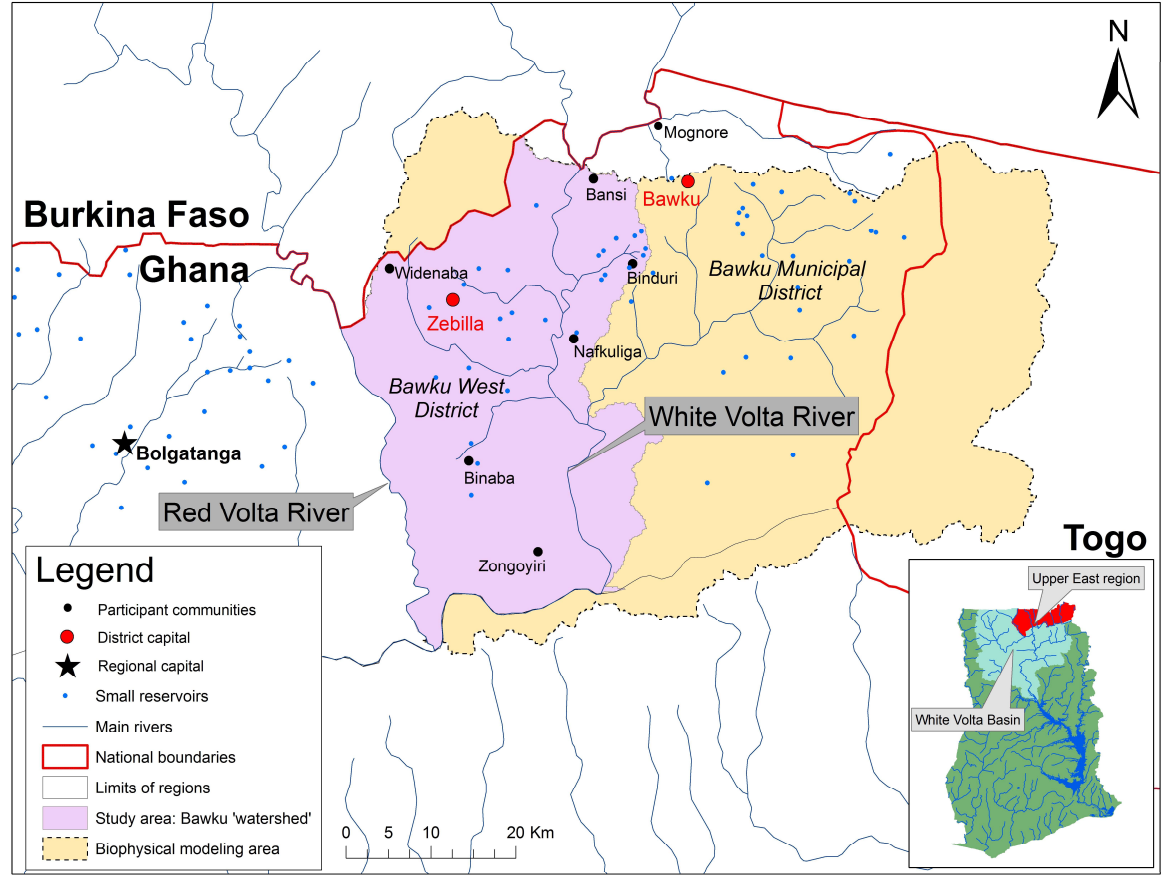

Figure 1. Main features of the study area.

\subsection{Study Area}

The study area is located along the main stream of the White Volta River. At the time of the project, it spread over two districts: Bawku West (called also Zebilla) on the right bank, and Bawku 
Municipal on the left bank of the river. This area was selected on the basis of discussions with the White Volta Basin Officer. It reflects the bias of the White Volta Basin Board toward the Upper East Region, and also reflects concerns over river bank erosion and the ongoing policy debates on the need to establish "buffer zones" along river streams where agricultural activities would be banned to limit sedimentation and the related increased incidence and impacts of floods. The delineation of the study area (in purple in Figure 1) is in itself a result of the participatory process, and marks a first and significant adaptation of IWRM principles. As said in the introduction, the study area defines a "problemshed" [24] rather than a watershed; it is limited by the Burkina Faso border to the North, the red Volta River to the West, the White Volta to the South, and a loosely defined border respecting hydrological boundaries to the East. Although participation in the multi-stakeholder process was not determined by hydrological boundaries, it was informed by it. Biophysical modeling (of erosion and water flows) was indeed conducted for a larger watershed, as represented in yellow in Figure 1.

The study area in purple is inhabited by about 200,000 people, with the highest population density along the White Volta River, on the left bank in the Bawku Municipal district. Kussasis, Mamprusi, Bissa, and Moshies are the most common ethnic groups in the area, where more than $80 \%$ of the population is rural and relies on rainfed agriculture during the rainy season and livestock rearing (cattle, goats, sheep, and poultry). It is one of the poorest regions of the country. There is limited irrigation in valley bottoms and around the many small reservoirs that dot the area (the blue dots in Figure 1). Fishing, hunting, the exploitation of forest resources (for firewood and charcoal), small-scale gold mining, and small-scale agro-industries are other major economic activities. The main crops grown are millet, sorghum, maize, rice, sweet potatoes, and peanuts, and average yields are low compared with other regions of Ghana. Vegetables (tomatoes, onions, soybeans, okra, and watermelon) are cash crops that are mainly produced along the banks of the White Volta or around small reservoirs $[26,27]$. In this dry zone, water availability and hydrology have a significant bearing on landscapes and the population: river flows can be both a blessing and a curse, as agricultural activities that depend on river flows are also vulnerable to seasonal floods.

\section{A Three-Year Multi-Pronged Participatory Process}

We now describe the participatory process that was designed and implemented over a three-year period. The core researchers made a methodological choice in consultation with the White Volta Basin officer when developing the research proposal: that of using a "Companion modeling" approach (ComMod). The main characteristic of ComMod when compared with other participatory approaches is the design and use of intermediary objects and tools (agent-based models, role-playing game, participatory maps, etc.) by different actors who have an interest in collectively solving issues that pertain to natural resources management [28]. Indeed, the core researchers considered that approaches such as mediated modeling [29] and companion modeling [28,30] allowed for generating a shared level of information among participants, creating common knowledge, exploring common goals, and understanding the views, interests, and rationale of opposing parties. The progressive building of a shared representation, as modeled through specific simulation tools, would eventually allow testing alternative management scenarios. In the process, participants would learn from their interactions with others during key collective moments such as participatory workshops.

Figure 2 shows the overall organization of the three-year participatory process that we designed and implemented from March 2010 to September 2013. We then provide further details on the objectives, participants, and tools that were used in each phase of the process (see also Table 1). 
Table 1. Main characteristics of the activities performed during the participatory process.

\begin{tabular}{|c|c|c|c|}
\hline Phase & Facilitators and Participants & Activities & Objectives \\
\hline $\begin{array}{l}\text { PREPARATORY } \\
\text { DISCUSSIONS }\end{array}$ & $\begin{array}{l}\text { Core researchers } \\
\text { Core researchers and computer modelers }\end{array}$ & $\begin{array}{ll}\text { - } & \text { Set strategic objectives for the design meetings and } \\
\text { participatory workshops (PW) } \\
\text { - } \quad \text { Propose a structure for the DMs and PWs } \\
\text { - } & \text { Propose a preliminary plan for the PWs }\end{array}$ & $\begin{array}{l}\text { Preparing the internal design meetings and } \\
\text { participatory workshops (PW) }\end{array}$ \\
\hline $\begin{array}{l}\text { VISIONARY TEAM } \\
\text { MEETING (VT) }\end{array}$ & $\begin{array}{l}\text { Core researchers + White Volta Basin } \\
\text { Officer } \\
\text { Core researchers + experts }\end{array}$ & $\begin{array}{l}\text { First "expert assessment" of the natural resources } \\
\text { issues at stake in the study area } \\
\text { Identify the type of people who needed to be part of } \\
\text { the project, and the modalities of their engagement } \\
\text { (objectives, change expected, pitfall to avoid, } \\
\text { potential tools, and methods) }\end{array}$ & $\begin{array}{ll}\text { - } & \text { Refining the engagement strategy } \\
\text { - } & \text { Legitimacy building vis-à-vis key decision makers }\end{array}$ \\
\hline $\begin{array}{l}\text { INTERNAL DESIGN } \\
\text { MEETINGS (DM) }\end{array}$ & $\begin{array}{l}\text { Core researchers } \\
\text { Core researchers + project team members }\end{array}$ & $\begin{array}{l}\text { - Design, calibration, and dry run of participatory tools } \\
\text { - } \\
\text { - }\end{array}$ & $\begin{array}{l}\text { Ensuring consistency between strategic objectives, } \\
\text { activities, and tools used in the project } \\
\text { Fine tuning the objectives and implementation } \\
\text { modalities of participatory workshops }\end{array}$ \\
\hline $\begin{array}{l}\text { PARTICIPATORY } \\
\text { WORKSHOPS (PW) }\end{array}$ & $\begin{array}{l}\text { Core researchers + White Volta Basin } \\
\text { Officer } \\
\text { Core researchers + project team members } \\
+ \text { stakeholders }\end{array}$ & $\begin{array}{l}\text { Group and plenary working sessions around the use } \\
\text { and refinement of participatory tools such as } \\
\text { participatory mapping, role-playing games, and } \\
\text { agent-based models }\end{array}$ & $\begin{array}{ll}\text { - } & \text { Eliciting information from and providing an arena for } \\
\text { exchange between stakeholders } \\
\text { - } & \text { Initiating a multi-level dialogue } \\
\text { - } & \text { Identifying knowledge gaps }\end{array}$ \\
\hline FOLLOW-UP INTERVIEWS & $\begin{array}{l}\text { Project team members (Interns) } \\
\text { stakeholders }\end{array}$ & Interviews with participants to the PW & $\begin{array}{l}\text { Obtaining feedback on the process and tools used in } \\
\text { the PW } \\
\text { Identifying potential issues of concern regarding } \\
\text { natural resources management not spelled out during } \\
\text { the PW }\end{array}$ \\
\hline $\begin{array}{c}\text { STUDIES ON } \\
\text { CROSS-CUTTING ISSUES }\end{array}$ & $\begin{array}{l}\text { Project team members (Interns) } \\
\text { stakeholders }\end{array}$ & $\begin{array}{l}\text { Thematic interviews and focus group discussion with } \\
\text { people operating in the study area }\end{array}$ & Filling knowledge gaps to inform subsequent PWs \\
\hline BIOPHYSICAL MODELING & $\begin{array}{l}\text { Computer modelers } \\
\text { Project team members and stakeholders }\end{array}$ & Desk modeling & $\begin{array}{l}\text { Providing biophysical data (land cover, quantification } \\
\text { of erosion, and flood patterns) to support the } \\
\text { elaboration of the tools used in the PW and } \\
\text { discussing relationships between human-induced } \\
\text { erosion and incidence of floods }\end{array}$ \\
\hline
\end{tabular}




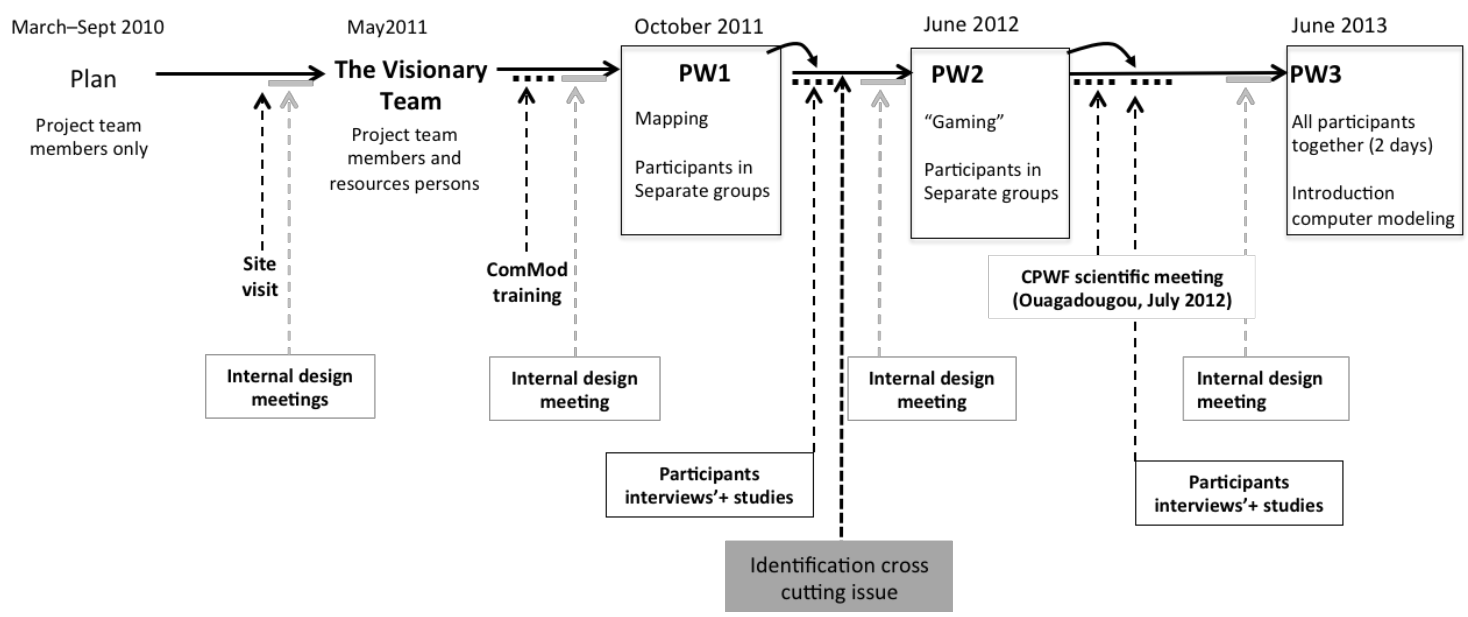

Figure 2. The main steps of the multi-level participatory process facilitated by the Challenge Program for Water and Food (CPWF) V4 project.

\subsection{The Initiation Phase}

In the first phase (March-September 2010), the research team and the White Volta Basin Officer (WVBO) of the WRC, engaged with scientific and institutional partners, and collectively refined the overarching objective of this transdisciplinary water research project towards "enhancing cross-level interactions to support IWRM implementation in the Northeast of Ghana". As mentioned above, the researchers proposed involving participants from various levels into a participatory modeling process. The first step of the participatory process per se was the organization of a meeting with four individuals that the WVBO and researchers had identified as knowledgeable regarding IWRM in the Upper East Region. These individuals had different and complementary backgrounds, and included one Ghanaian researcher, a traditional chief involved in natural resources management issues in the area, a former high-level official of the regional administration, and a project manager of a Ghanaian non-governmental organization (NGO) also operating for several years in the Upper East Region of Ghana.

\subsection{The Visionary Team Meeting}

The first collective moment of the participatory process was what we dubbed the "visionary team" (VT) meeting. It was held in May 2011, and brought together the two researchers coordinating the project: the White Volta Basin Officer and the four high-level experts mentioned above. As indicated by its name (which was suggested by the White Volta Basin Officer), the visionary team helped develop a vision of the project's participatory strategy. This was done after the researchers presented the key components and underpinning rationale of the ComMod approach (see above). This workshop allowed discussing and refining the overall trajectory that the project would follow (notably the need to organize several participatory workshops), but yielded little specific information on how to implement it. Further, only one of the high-level experts who participated in this meeting contributed to the subsequent project's activities, and the core researchers seldom reverted back to the outcomes of this meeting, which existed in the form of working documents.

\subsection{Participatory Workshops (PWs)}

The "visionary team" meeting identified the need to organize multi-stakeholder workshops. These were thought of as participatory working sessions, which constituted "key collective moments" [28]. These collective moments were designed to progressively bring individuals and organizations operating at different decision-making levels (community, district, and regional levels) together. In the context of potential power asymmetries, operating "step-by-step" was deemed necessary so as 
to enable the expression and sharing of viewpoints that different stakeholders could have regarding natural resource management issues in the study area. While enhancing the emergence of a collective matter of concern among the various types of participants engaged in this process, we thought that the "Bawku problemshed" would progressively emerge.

\subsubsection{Structure and Participants}

Three participatory workshops (PW in Figure 2) were organized, with each immediately preceded by a "design meeting" among project team members. Initial ideas of the core researchers were adapted several times, first during the internal design meetings, but also during the participatory workshops themselves, so as to incorporate issues that emerged during the workshops (see below).

The first two participatory workshops (PW1 and PW2) were conducted in October 2011 and June 2012, respectively, and followed the same "model". During the first two days, discussions were held in the meeting room of the District Assembly of Bawku West (in Zebilla for the first PW) and Bawku Municipal (in Bawku for the second PW), respectively. Each time, the third day of the workshops was held in the regional capital, Bolgatanga, in the meeting room of the White Volta Basin Board. Each day of the workshops was devoted to a specific "decision-making level", that is, community members and agricultural extension agents operating in the study area participated on the first day; district administrative staff, NGO representatives, the elected representatives of communities, and traditional authorities of the two districts of Bawku West and Bawku Municipal participated on the second day; and representatives from sectoral ministries and regulatory bodies at the regional level, regional NGOs, and regional traditional authorities contributed to the third day of the PW. During and between the first two PWs, an exchange of information across decision-making levels was coordinated by project team members who presented the results that were obtained on any given day with specific participants to the individuals who were contributing to the subsequent days of the workshops.

The third participatory workshop (PW3) and last collective moment of the process was conducted in June 2013. It differed from the first two PWs, as it provided an arena for direct interactions between individuals and organizations operating at different decision-making levels over two days. Following discussions that occurred during the first formal meeting of the WVBB since its creation (in August 2012), the White Volta Basin Officer (WVBO) proposed that PW3 centered on identifying strategies to perpetuating the nascent multi-level dialogue. For this purpose, it was decided that PW3 should aim at assessing the willingness of participants to establish a "mini board" that could deal with IWRM issues in relation to the Bawku problemshed (see below).

\subsubsection{Activities and Tools}

PW1 revolved around participatory mapping exercises to collect information on (i) the natural resources system (and more specifically water); (ii) agricultural practices; and (iii) regulations to control the access to and use of natural resources and limit environmental degradation. To do so, we used inclined "white" wooden panels that were meant to represent a watershed on which participants were asked to stick colored post-it notes identifying their concerns and where they were relevant (see Figure 3). 


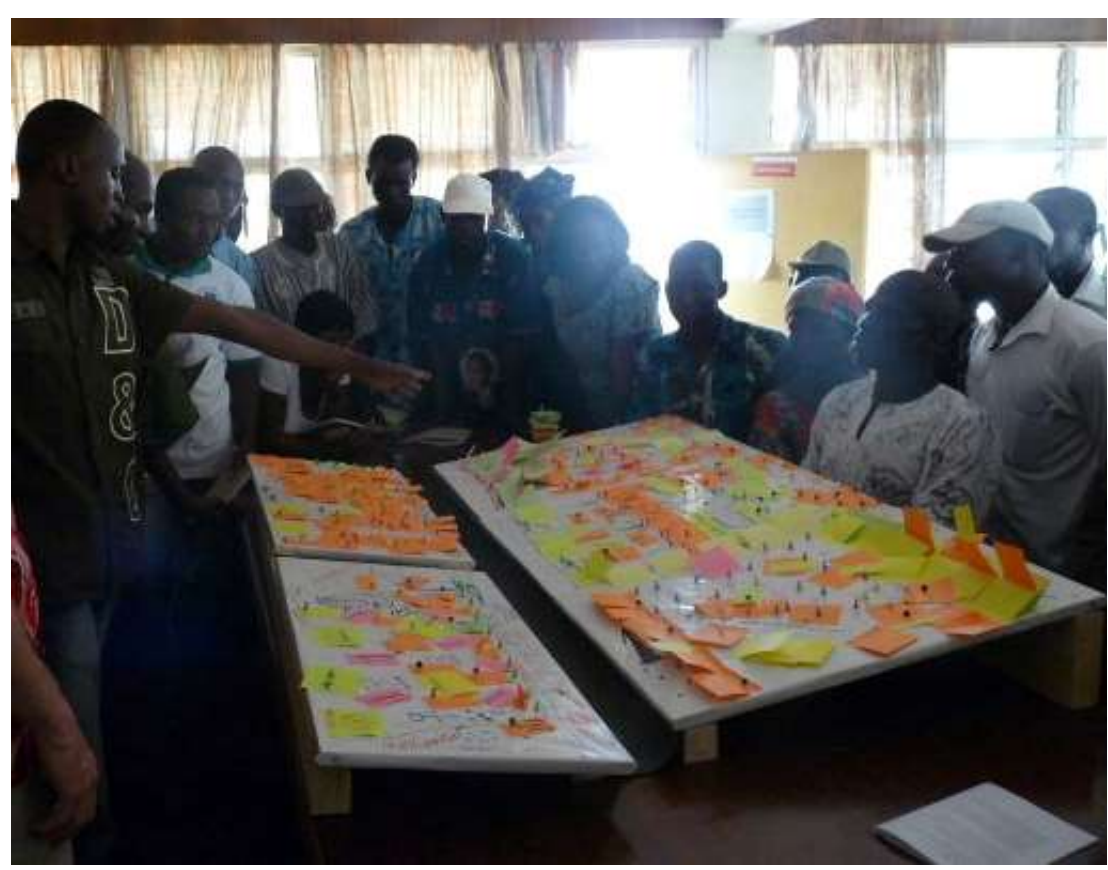

Figure 3. Material used in participatory workshop 1 (PW1): nested inclined white wooden panels (representing different portions of a watershed) and colored post-its and pins representing different land-use types.

By listing issues of concerns for different groups of participants and envisioned regulations, PW1 was also the first step towards the identification of a common issue that could prove conducive to initiating a cross-level dialogue (Table 2 below clearly shows some overlap, as well as differences among the issues that different groups identified as of being of concern). Of specific interest is that the issues of river bank cultivation and soil degradation (or erosion) emerged in all of the groups; this would lay the basis of the identification of the "problemshed" (see below-the other common issue to all of the groups was that of deforestation and the control of forest resource use). 
Table 2. Issues identified by the participants during the first participatory workshop. WRC: Water Resource Commission.

\begin{tabular}{|c|c|c|c|}
\hline Area & Community Level & District Level & Region Level \\
\hline $\begin{array}{l}\text { White Volta Right bank } \\
\text { (Zebilla district) }\end{array}$ & $\begin{array}{ll}\text { - } & \text { Difficulty to control bush-burning } \\
\text { practices in forest areas } \\
\text { - } \quad \text { Differential access to water } \\
\text { resources (boreholes or small } \\
\text { reservoirs among villages) }\end{array}$ & $\begin{array}{ll}- & \text { Land degradation (due to } \\
\text { overgrazing and bush burning) } \\
\text { - } & \text { Gold mining } \\
\text { - } & \text { Siltation of river and } \\
\text { small reservoirs } \\
-\quad & \text { Water pollution (chemicals) } \\
- & \text { Loss of crops and livestock due } \\
\text { to floods } \\
-\quad & \text { Health issues (black fly) } \\
- & \text { Use of forest resources and } \\
\text { cultivation in forest areas }\end{array}$ & \begin{tabular}{ll}
\multicolumn{2}{l}{ Environmental issues } \\
- & Deforestation \\
- & River bank cultivation \\
- & Gold and sand mining \\
- & Siltation of river and small reservoirs \\
- & Heavy use of pesticides and fertilizers \\
- & Water pollution (chemicals) \\
- & Poor sanitation and related health hazards \\
- & Floods and their consequences on \\
& livelihoods and pollution
\end{tabular} \\
\hline $\begin{array}{l}\text { White Volta Left bank (Bawku } \\
\text { Municipal district) }\end{array}$ & 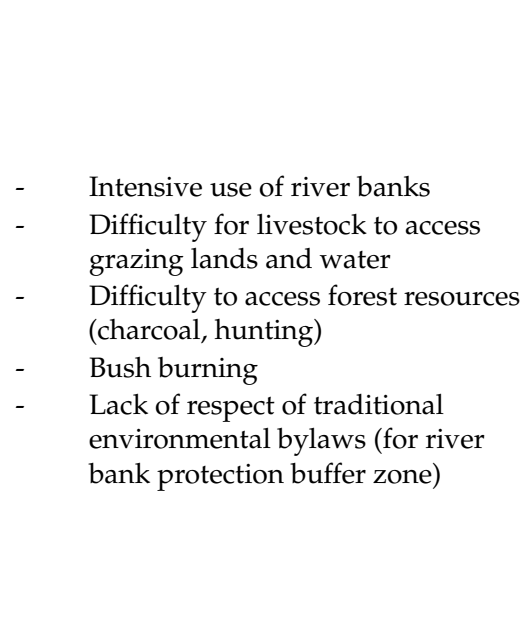 & $\begin{array}{ll}- & \begin{array}{l}\text { Land degradation (due to } \\
\text { overgrazing and bush burning) }\end{array} \\
- & \text { Sand mining } \\
- & \text { Erosion and small } \\
\text { reservoir siltation } \\
- & \text { Use of chemicals for fishing } \\
- & \text { Loss of habitat and ecological } \\
\text { diversity due to floods } \\
-\quad & \text { River bank cultivation } \\
- & \text { Deforestation } \\
- & \text { Difficulty to enact bylaws (for river } \\
\text { bank protection buffer zone) }\end{array}$ & $\begin{array}{l}\text { Difficulty to implement existing regulations } \\
\text { - } \quad \text { Community by-laws regarding bushfire } \\
\text { control and tree cutting that are enacted by } \\
\text { traditional authorities } \\
\text { - } \quad \text { Forestry Act not respected } \\
\text { - } \quad \text { Use of chemicals in fishing and pesticides } \\
\text { in agriculture } \\
\text { - } \quad \text { Gold mining practices (use of mercury) } \\
\text { Missing or inadequate regulations } \\
\text { - } \quad \text { About the misuse/disposal of } \\
\text { agrochemicals and livestock and } \\
\text { domestic waste } \\
\text { Multiplicity of buffer zone regulations (to } \\
\text { limit river bank cultivation) across } \\
\text { different organizations (Ministry of Food } \\
\text { and Agriculture, Environmental Protection } \\
\text { Agency, Water Resources Commission }\end{array}$ \\
\hline
\end{tabular}


A role-playing game called Bawkudo (in addition to making a reference to the study area "Bawku", the name of the role-playing game sounds like "beaucoup d'eau", which means "lots of water" in French. This appeared adapted to a role-playing game notably dealing with flooding) was used during the first day of PW2 (see Figure 4). Its objectives were to: (1) validate project team members' interpretation of the results of PW1; (2) identify agricultural practices and refine collective understanding of existing environmental regulations, notably regarding bush burning and river bank cultivation (which had emerged as key concerns during PW1, see Table 2); and (3) discuss the implications that floods and regulations might have on food security at household, district, and regional levels.

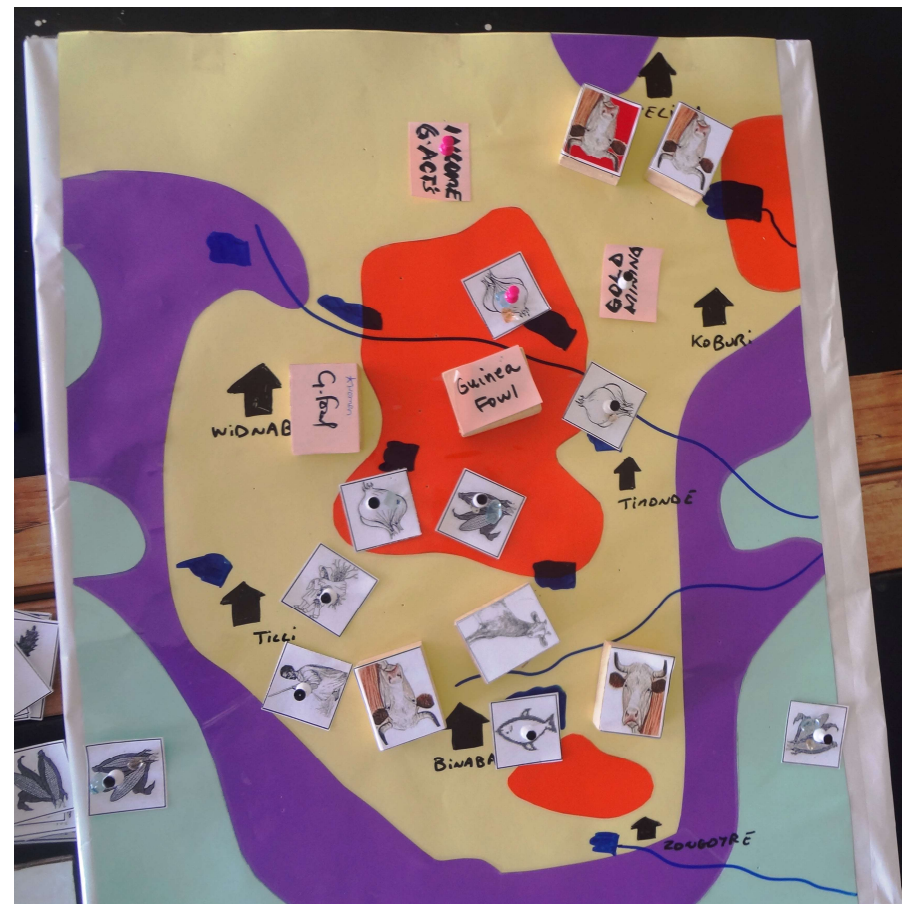

(a)

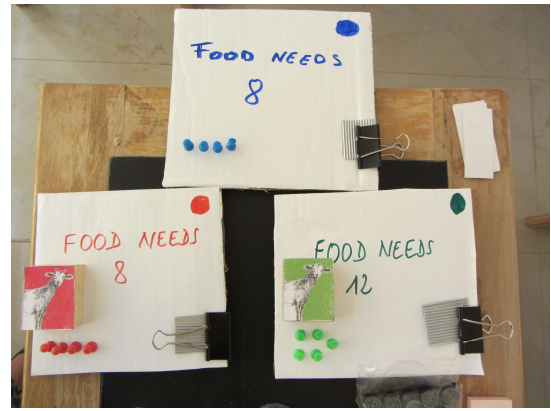

(b)

Figure 4. Bawkudo role-playing game (a) inclined wooden panel indicating landmarks and four types of land cover (in green, the forest area; in purple, rangeland; in yellow, mixed vegetation; in orange, cropland), with stickers indicating agricultural activities identified by players; (b) three players' pads indicating an objective of food production to be reached by the household through a specific number of agricultural activities (represented by colored pins).

The extent and shape of the different land-cover types (see Figure 4a) were obtained by cross-referencing the participatory maps drawn during PW1 and a land-cover map derived from satellite images. The use of satellite imagery led to adding one type of land cover to the three that had been identified during PW1. The names of the different types of land cover reflected the terminology used by participants on PW1. During the second day of PW2, participants collectively worked on the identification of measures to limit river bank cultivation and bush burning. Provided with the list of environmental issues that they had identified during PW1 (see also Table 2), participants chose the most important issues for further discussion. All of the groups decided to brainstorm on possible ways to control bush burning or limit river bank cultivation. The project team sought further information by asking the following questions: what would be the rules (notably where and in which season would they apply)? Who would be responsible for their implementation? How would they be implemented (practice, incentives, sanctions) and monitored? How flexible should the rules be? A static agent-based computerized version of the wooden panels was also used to display the farmers' agricultural decisions that had been recorded during the first day of PW2 to the regional level participants on the third day 
of the meeting. This tool enabled qualitatively assessing the potential consequences of floods on food security at household, district, and regional levels.

The first day of the PW3 was divided in three sessions. During the first session, farmers were split in two groups (one for each side of the White Volta River), and re-played the Bawkudo game as a refresher of previous PW. In the meanwhile, district and regional decision-makers played, in separate groups, the Bushbank game, whose aim was to highlight that they, themselves, faced constraints (in terms of human, financial, and social capital) to implement the rules and regulations they deemed necessary and had identified in the first two PWs. The Bushbank game differed from Bawkudo by the set of stickers to be pinned on the board by participants. Stickers represented measures that could be implemented to limit bush burning and river bank cultivation (volunteers training, sensitization activities, monetary fines, planting of trees, drilling of wells, provision of free fertilizers, etc.; these had been identified in the second PW) instead of agricultural practices (see Figure 5). In this first session, the bushbank game was played without communication between players; each individual decided the activities s/he thought were important to implement, and the members of the district groups were then asked to "pin down" the measures that they had identified on the wooden panels that represented "their district"; the regional group did not do that. On the second session of day one, members of the district groups were split in two: some went to discuss with farmers to inform them where they wanted their measures to be implemented (using the Bawkudo board where agricultural activities were represented as a support of their discussion), others went to discuss with regional decision-makers to be informed of their priorities. On the third session of the day, each district and region group played the bushbank game (this time, discussing among individuals within each group was allowed) and the farmers played Bawkudo after having been informed of the measures that the district officers envisioned to implement. The objective was to see if improved information would lead to significant changes in practices and regulations. At the end of the day, open discussions were held to get further information on farmers' rationale for bush burning and river bank cultivation.
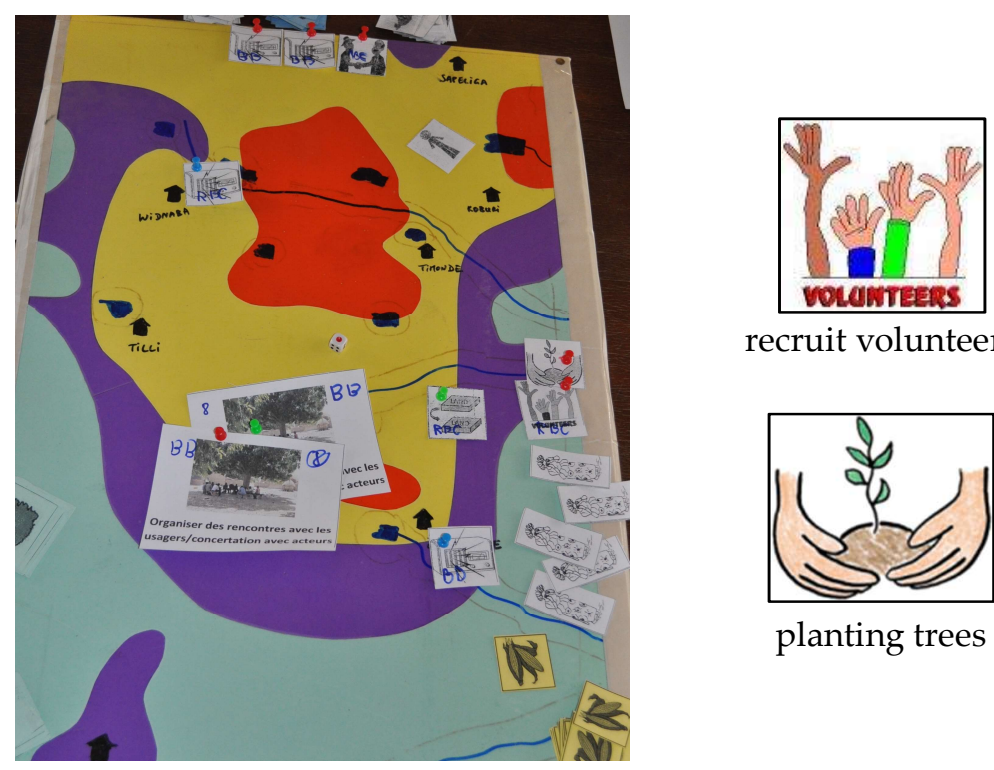

recruit volunteers

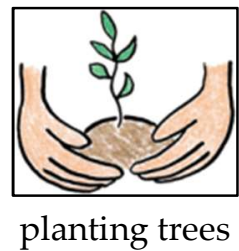

Figure 5. Bushbank board game (left), similar to Bawkudo (here the right bank of the White Volta River) and two examples of stickers (right) representing activities district players locate on the board.

On the second day of PW3, the focus was put on the issue of river bank cultivation and simpler facilitation techniques. We formed two groups for each bank of the river: one with farmers and assembly members, and one with district and regional representatives. First, the four mixed groups of participants were asked to evaluate how the six different measures (volunteers training, sensitization activities, monetary fines, planting of trees, drilling of wells, and the provision of free fertilizers) 
identified by district and regional officials to limit river bank cultivation would impact the environment and food production. In each group, open discussions were conducted that yielded a table with positive and negative attributes for each measure (with a scale from -3 to +3 ). Then, for each bank of the river, each group swapped to see the results of the second one. Second, another exercise was organized with two groups, each of which combined participants from the three decision-making levels. They were asked to rank the relevance of these measures and how efficient they would be in inducing a change in practice (i.e., the conditions under which farmers would stop river bank cultivation). The results showed that a consensus emerged across all of the groups around the fact that the provision of free fertilizers and pumps and the planting of trees were the most likely to be effective to that end, given the constraints that different actors faced (and which had been stressed during the first day of the workshop). Before closing the workshop, we showcased an agent-based computerized model designed by the modelers of the research team. The objective of this model was to illustrate how land use would change according to different scenarios: (1) business as usual (see Figure 6); (2) sensitization meetings conducted-with little impact on farming practices and the extent of river bank cultivation; (3) planting of trees along river banks and no additional incentives; (4) planting of trees along river banks and supply of inputs for farmers to cultivate alternative land. The agent-based model was also used to show how food production would be affected by episodic floods in the different scenarios (impacts being the highest in scenario one and the lowest in scenario four). In keeping with the overall objective of the workshop (i.e., testing the willingness of different individuals and organizations to contribute to the activities of a multi-level "bridging organization" for land and water management in the area), an open discussion on the relevance to formalize the interactions that had been initiated during this third PW was conducted.

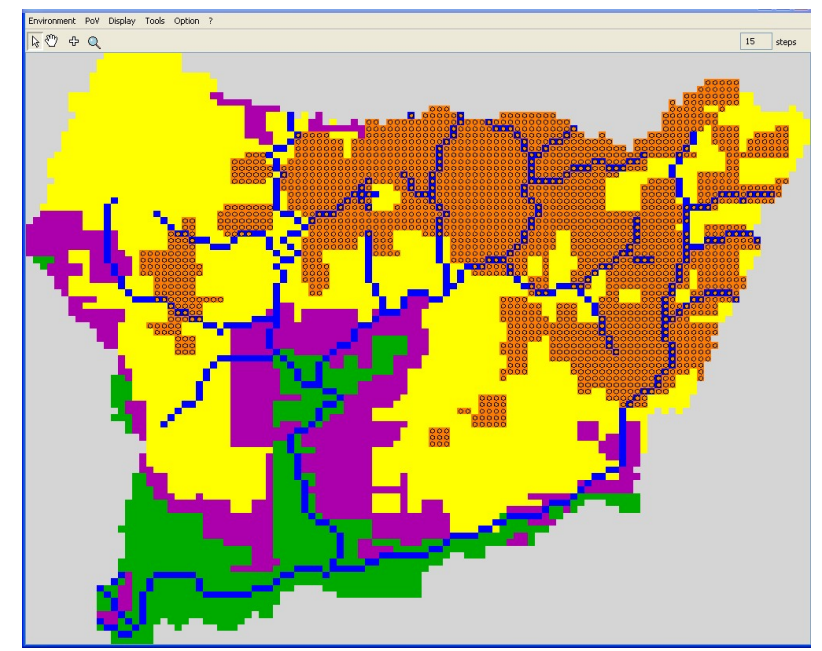

Figure 6. Land use of the "business as usual" scenario in 15 years' time with the expert-based agent-based model (in green, the forest area; in purple, rangeland; in yellow, mixed vegetation; in orange, croplands).

\subsection{Other Activities}

In addition to these key collective moments, other activities were conducted by the project team. These included a working session in July 2012 in which the Bawkudo role-playing game was used by Burkinabe decision-makers and water users for discussing the pros and cons, and the modalities of implementing regulations aimed at limiting river bank cultivation (which is also a topic of debate in Burkina Faso). Specific studies were conducted on topics that emerged during participatory workshops and about which the project team lacked information. For instance, interns studied the role of traditional authorities [31] and district assemblies and NGOs [32] in regard to natural resources management, and women organizations and the inclusion of gender issues in water 
resources management policies [33]. Between each PW, core researchers also conducted follow-up interviews with a selected number of participants to the PW. These interviews also served to validate the outcomes of the preceding PW (notably regarding the identification of the problemshed that would allow for initiating a cross-level dialogue; see below) and yielded information that would be incorporated in the following PW. Finally, participatory observation by project team members during the PWs also served a key role to inform subsequent PWs.

\section{Discussion: Reflexive Analysis of the Process and Identification of a Shared Problemshed}

\subsection{Adjusting Tools to Participants and Feedback Received}

As said above, the use of "tools" around which a multi-level dialogue could be initiated and facilitated constituted a pillar of the project's approach. Using tools as boundary objects [34] and alternating group work and plenary discussions, we first established direct interactions between individual and organizations operating at the same level of decision-making, and then created an arena for direct interactions across the levels. Interestingly, community members were the most at ease with the Bawkudo role-playing game (likely because it allowed simulating their daily cultivation practices), while regional representatives faced difficulties using it, which revealed a lack of place-specific knowledge on farming practices. Conversely, regional representatives were very much at ease with plenary and group discussions (without tools and materials), and community members were less active in these, especially when they involved representatives from district and regional authorities-again highlighting the importance of power differentials among stakeholders. This is a clear illustration of the importance of tools in participatory processes and transdisciplinary research, and how they can "work toward" reinforcing or attenuating power relationships. The type of tools to be used in the participatory workshops was largely decided during internal design meetings among project team members; however, their exact content was largely defined during the participatory workshops among a wider set of stakeholders, with for instance:

- The involvement of representatives of two communities that had not been identified by project team members following interviews conducted after PW1. For instance, the community of Mognore (in the north, outside of the watershed boundaries, see Figure 1) was added because participants (community and district) wanted to benefit from what they considered as the community positive experience in terms of river bank regulation;

- The extension of the portfolio of agricultural activities available to participants, notably through the introduction of activities conducted by women (poultry rearing, beans, and groundnut cultivation). This was done in the midst of PW2, as women farmers highlighted that the stickers they were provided did not allow them to represent their own practices;

- Ensuring that women played the Bawkudo game. As PW2 started, the facilitators observed that women did not engage with the Bawkudo board game when in mixed groups. It was then decided to set a "women group" that would play separately from men on a dedicated (and identical) board game.

A second set of adaptations relates to the very tools that were developed, namely the Bawkudo and Bushbank games and the related computerized agent-based model. One of the main early hypotheses that underpinned our research effort was that the use of a unique tool with participants operating at different decision-making levels would lay the groundwork for the identification of an issue of common and collective interest, while limiting the expression of power relationships during the participatory workshops. This proved to be only partially true. The Bawkudo role-playing game (RPG) was new for all of the participants, and appeared particularly suitable to identify land-cover types (participatory maps and satellite imagery overlapped to a large extent) and farming practices. Community members provided important insights on how to improve the role-playing game so that it would better reflect the agricultural and environmental dynamics taking place in the study area. District-level representatives, 
in turn, identified "validity domains" where implementing different environmental regulations made sense to them. However, as mentioned above, regional representatives had difficulty engaging with Bawkudo. They were for instance unable to identify place-specific cultivation practices and seemed to consider that environmental issues affected the entire study area in a similar way. This uneasiness with Bawkudo contributed to building the legitimacy of community members' knowledge: regional representatives learned from farmers about the specifics of farming and the issues faced in specific areas. It also led us to develop a new game, "Bushbank", that focused on identifying the type of regulations to be implemented, which was also used with district representatives in PW3. Other significant adaptations were made at the end of the first day of PW3. The design meeting preceding PW3 had allowed identifying activities for the first day of the workshop, but the content of the second day was largely left open. Based on the discussions that took place, the project team decided to center the discussions and activities of the second day on the issue of river bank cultivation and flooding (leaving aside the question of bush burning). The project team considered that this issue was more amenable to highlighting cross-level and spatial interactions. Newer and simpler (than a role-playing game) forms of interactions were designed from scratch by the project team in the evening of the first day of the workshop, and the computer modelers focused on designing a model that would simulate trade-offs between two indicators: one related to environmental preservation (using the extent of forest cover as a proxy), and the other related to food production according to the different extents of river bank cultivation and the random generation of flood events. This paved the way for a final discussion focusing on possible ways forward.

\subsection{Adjusting Facilitation Techniques: from Mediated Exchanges to Cross-Scale Knowledge Generation}

One of the major difficulties in multi-level participatory projects is about facilitating direct interactions between individuals and organizations that operate at different levels. They indeed do not belong to the same social system, and even in the absence of direct interactions, power discrepancies might hamper some participants to express their views and others to listen, thus hindering dialogue. To avoid this pitfall, we designed the participatory tools and activities so that participants could "mimic" their usual practices (farming for community members, organizing or regulating farmer's activities for region and district participants), while the overall process was designed to progressively elicit interactions between participants, as illustrated in Table 3.

Table 3. Structure of participation. PW1: participatory workshop 1; PW2: participatory workshop 2; PW3: participatory workshop 3.

\begin{tabular}{|c|c|c|c|}
\hline PW1 & PW2 & PW3 Day 1 & PW3 Day 2 \\
\hline $\begin{array}{l}\text { Group formed along } \\
\text { community lines (day } 1 \text { ), } \\
\text { function lines for each } \\
\text { district (day 2), and } \\
\text { arbitrarily (day } 3 \text { ) } \\
\text { Feedback in plenary }\end{array}$ & $\begin{array}{l}\text { Intense interactions } \\
\text { across same-level actors } \\
\text { Structured group } \\
\text { discussion with district } \\
\text { and regional } \\
\text { decision-makers about } \\
\text { bush burning and river } \\
\text { bank cultivation } \\
\text { regulations }\end{array}$ & $\begin{array}{l}\text { Interaction via the games } \\
\text { between two levels: } \\
\text { farmers and district; } \\
\text { district and region } \\
\text { Farmers played Bawkudo } \\
\text { while decision-makers } \\
\text { played Bushbank }\end{array}$ & $\begin{array}{l}\text { Direct interactions } \\
\text { across the three levels }\end{array}$ \\
\hline
\end{tabular}

We made the hypothesis that structuring the process as such would be a way for participants to voice their opinion, listen to the representations and perceptions of others, and recognize these as being legitimate, too. Second, we expected to limit, to a certain extent, the expression of power by giving devoted time and space to different participants so that they could express their views without worrying how people with more leverage may behave in the face of such clarification (the PW were not free from non-reciprocal interactions. At any one level (community, district, region), hierarchical relationships do exist and had a bearing on the PW (see for instance, the case of gender in Section 4.3). 
During and between the first two PWs, the project team coordinated an exchange of information across levels. It mostly took the form of PowerPoint presentations of the activities conducted, and results obtained, by any given set of participants to the others, at the start of each day of the workshops. As a rule of thumb, individuals who proved the most dynamic were invited in subsequent PWs (keeping a balance between communities, sectors, and gender remained the major criteria for participants' selection, even as the number of participants decreased).

During PW3 (in June 2013), interactions were more direct as community members, district representatives, and regional representatives were brought together over two days in the meeting room of the Bawku West District Assembly. We assumed that participants had become familiar with the principles of the ComMod approach, and notably the use of games, and felt comfortable enough to voice their opinion. The different facilitation techniques and the repeated reshuffling among groups (see Section 3.3.2) allowed avoiding the power differences having significant bearings on the direct multi-level interactions that occurred during PW3.

PW3 constituted a key moment for knowledge sharing and cogeneration. First, the assessment of the relevance-and related ranking —of specific measures to limit river bank cultivation was consensual among groups (day two of PW3, see Section 3.3.2). This reveals that, at the time, each type of participants (community members, district representatives, and regional representatives) knew about the agricultural practices in the study area, the formal and traditional regulations to limit river bank cultivation, the difficulties of implement them (not only because they were not respected), and their potential impact on food security (at household, district, and regional levels) and the environment.

Another example of knowledge cogeneration across decision making levels can be seen in the results of the second round of the Bushbank and Bawkudo games (see Section 3.3.2). Indeed, comparing activities and actions after communication had been established between different types of participants showed that players changed their action plan, notably by being more "focused". First, although district and regional officers envisioned implementing the same measures on both banks of the river before any communication was established, this was not the case after they interacted with farmers. On the right bank, we observed that district players envisioned reinforcing regulations in specific communities, while they did not think intervening along the White Volta River would be necessary anymore. This happened because they learned during their discussions with farmers that the latter did not cultivate on this river bank, but rather around the small streams and reservoirs located in the watershed. At the same time, farmers envisioned concentrating their activities around small reservoirs rather than along small streams, as they had done previously. On the left bank of the White Volta, where the population density was higher, farmers cultivated around small reservoirs and along small streams as well as on the White Volta river bank. Farmers did not change their practices even after they had discussed with district officials, arguing that high population density did not give them any choice. On the contrary, district representatives, whose measures were initially focused around small reservoirs, changed their focus and envisioned intervening more along the White Volta river bank.

\subsection{Building Transdisplinary Research: Roles and Positioning of Project Team Members}

Finally, engaging in transdisciplinary research requires recognizing and building synergies between the skills and knowledge that different participants have. This starts among researchers and project team members. A reflexive analysis of the process showed that members of the project team were not involved in the same ways in project planning, design, or implementation. Figure 7 shows how participants in the process could be pooled into five circles, depending on the intensity of the relationships between individuals and their level of implication in different activities. The two "core researchers" (1) who were based in the Volta basin for most of the project duration participated in the planning phase of the project, and facilitated all of the internal design meetings and participatory workshops. Together with the WVBO (2) representing the organization in charge of water policy-making in the White Volta Basin of Ghana, the core researchers steered the project and defined the strategic orientations. They had a key role in the day-to-day project management and 
engagement with partners and actors of the watershed, and in designing the Bawkudo RPG and other facilitation tools used during the PWs. Two other researchers formed a "computer modelers team" (3); they participated in all of internal design meetings and PWs, and worked to combine a biophysical model of the watershed (accounting for flooding and erosion dynamics) to an agent-based model supporting the Bawkudo role-playing game. These four researchers (groups one and three) were also the most familiar with the ComMod methodology, and interacted to prepare the time-bound collective moments of the project. Another arena of dialogue was that of the internal design meetings, which, in addition to the four researchers identified above, brought together interns as well as researchers who were less familiar with the project approach and objective (large thin purple circle in Figure 7).

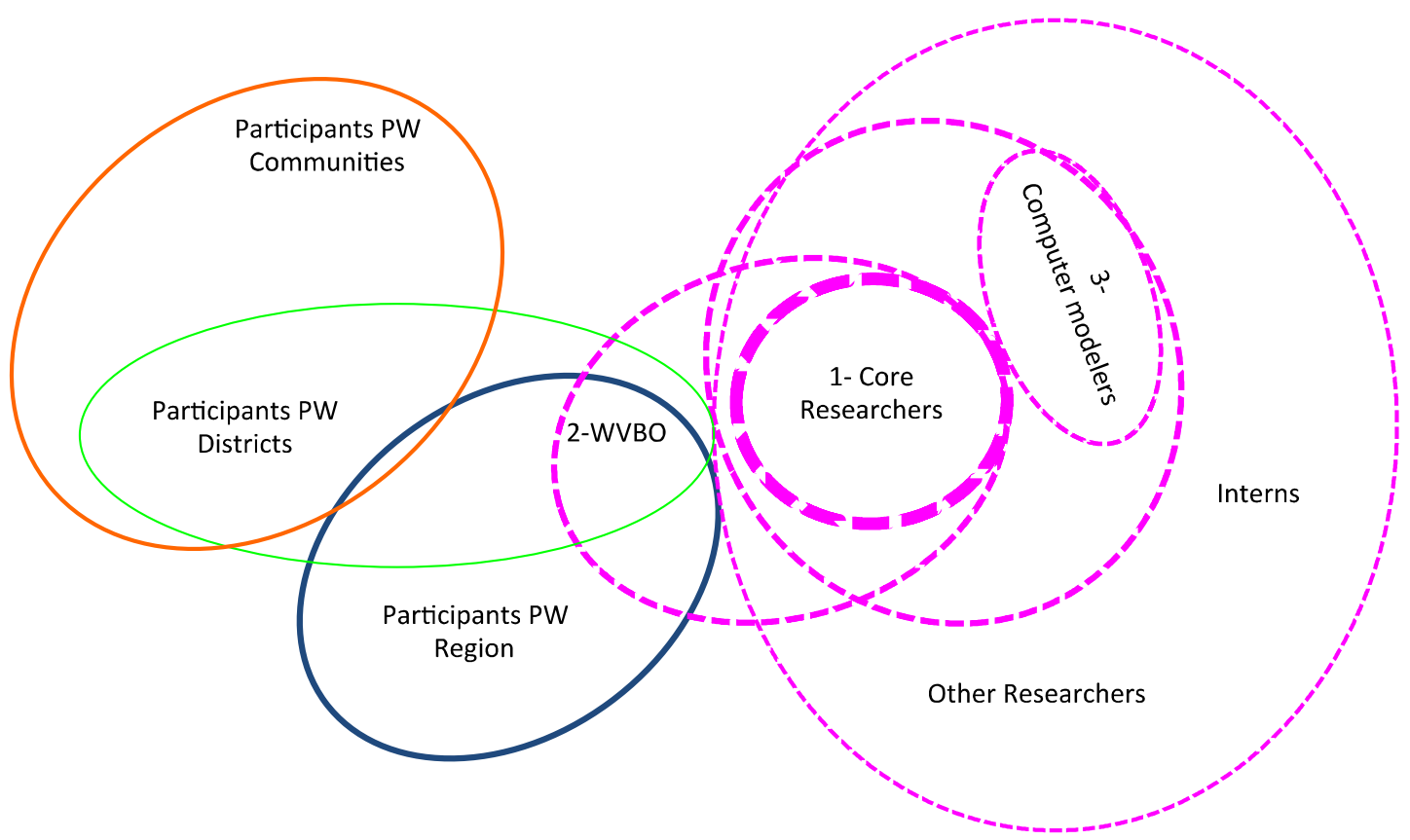

Figure 7. Interaction among and between project team members and problemshed actors according to the main roles they assumed in project activities. (Ellipses represent different "arenas of dialogue" in relation to project implementation. The dotted lines represent arenas and interactions that would not have existed without the project; plain lines represent interactions that exist regardless of the project activities [notably among watershed actors located on the left side of figure]. The thicker the line, the more intensive exchanges have been as part of the project. Purple indicates project team members; blue is used for regional representatives, green is used for district-level participants and orange is used for community-level participants).

Mixing people with different backgrounds and different levels of familiarity with the ComMod methodology had significant bearing on the way the project was implemented. This played out significantly during internal design meetings. These had been mostly thought of as 'practical activities' by the core researchers (to design and plan subsequent participatory workshops), but they largely turned out to be arenas in which the strategic objectives of the project were discussed and iteratively redefined, and in which the use of pre-defined tools was significantly questioned. Indeed, tools, were seen as artifacts of researchers' viewpoints that would shape participation in a specific direction of concern and interest for researchers, but not necessarily for the invited participants. Whether this was an appropriate approach and whether tools would really allow the emergence of other viewpoints than that of the researchers was a hotly debated-and unresolved-issue. However, this debate laid the groundwork for discussions stressing the need to ensure consistency between objectives and tools, and ensuring that the later served the former. The core researchers who were engaged in the daily project activities and management may have sometimes lacked the necessary distance to critically 
reflect on the tools they had envisioned using, or may have gotten bogged down in implementation details. This may have been the same for the computer modelers, who focused on linking biophysical modeling and agent-based modeling (ABM). The other researchers, who were less familiar with the ComMod approach or with the specificity of this experiment, provided a critical perspective about the project process and progress, especially regarding the use of pre-defined tools to trigger genuine participation. However, constructive engagement was made possible because they share a common understanding of the overall objective and basic principles that underpinned the approach. Further, the engagement of the WVBO in the project team was essential to ensure activities would be in line with the expectations of community members as well as district and regional officers (he also played a role in the organization of the meetings through relays in the local offices of the Ministry of Food and Agriculture and NGOs, which are long-term partners of the WVBB and the WRC).

\subsection{The Result of the Participatory Process: Framing the Bawku Problemshed}

Tools, facilitation techniques, and a reflexive analysis of the position of specific team members served the progressive co-identification of a "shared problemshed". This is the main result of the process, and a key element for transdisciplinary research to support innovative water governance. This happened as the "study area" was redefined on the basis of discussions held during and around the first participatory workshop. The study area was indeed (1) extended westwards to the Red Volta river where-much like the White Volta-river bank cultivation, deforestation, and small-scale gold mining were identified as key concerns by participants (rather than considering the White Volta watershed limit that falls between the red and white Volta rivers) and (2) limited eastwards to the vicinity of the White Volta river, due to the high population density there (see Figure 1). While the project team had initially envisioned working on the basis of watershed boundaries in line with the IWRM model, these boundaries did not "speak to" participants, and hence were changed.

In line with the refinement of the study area, what emerged was a "problemshed" centered on the issue of erosion, flooding, and river bank cultivation. Figure 8 is a schematic representation of this problemshed: farmers engage in river bank cultivation and/or bush burning because it has immediate beneficial impacts on their livelihoods (e.g., increased yields). By doing so, they also trigger erosion and soil degradation, hence potentially increasing the incidence and impacts of floods both on their livelihoods and at a wider scale (district/region) (erosion leads to streams and reservoir siltation, which in turns leads to lower storage capacity or reduced flow downstream, making the area prone to flooding along the river banks ever wider). In this context, district and regional decision-makers want to limit or ban river bank cultivation and bush burning through different regulations. These regulations are envisioned or enacted in the name of environmental preservation and in the perspective of limiting future risks, but they would also negatively affect local livelihoods. As such, they are disputed and difficult to implement.

Though they approached the related issues of river bank cultivation and erosion/flooding from different vantage points, what clearly emerged from the discussions is that all of the participants to the process had a stake in finding an agreeable solution to this "problemshed". On one hand, district and regional decision-makers wanted regulations to be implemented-not ignored-without having to use politically sensitive coercive measures. Farmers, on the other hand, were not opposed to these regulations per se, but wanted to engage in productive livelihoods activities. This conundrum laid the basis for identifying a potential intervention centering on the distribution of subsidized inputs for balancing the yield losses incurred by farmers who accepted moving away from the river banks.

How this could be implemented "practically" was discussed at the end of the third participatory workshop and, following a suggestion of the WVBO, participants settled on the need to establish what they termed a "mini board", which would bring together the different actors involved. This idea of establishing multi-stakeholder organizations that could address issues of concern over less widespread areas has been mainstreamed since then. Indeed, the WRC is currently reviewing its approach to 
IWRM and envisioning creating sub-basin boards in a classic pyramidal approach, thus addressing one of the difficulties it has faced until now: that of vertical integration.

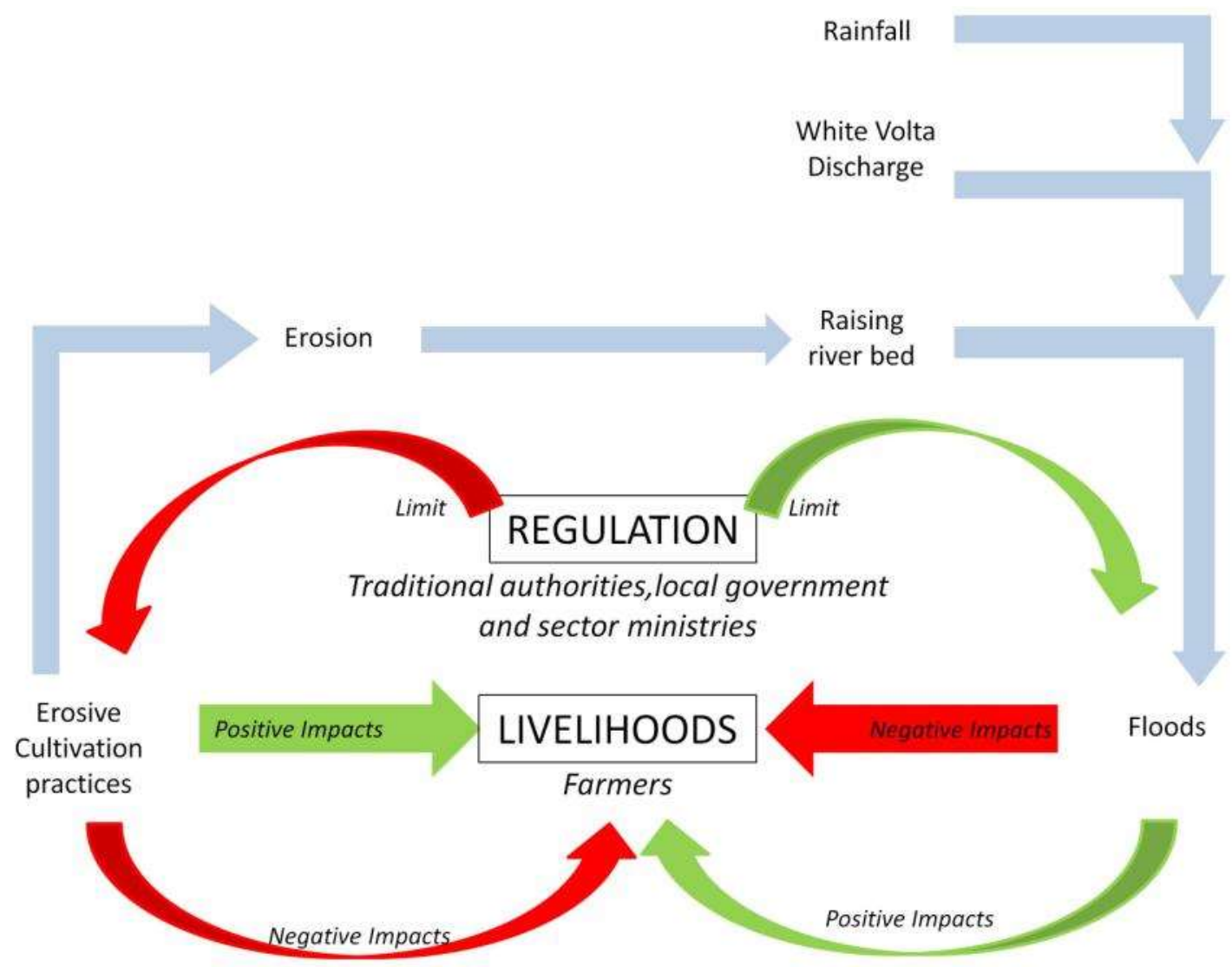

Figure 8. Schematic illustration of the Bawkudo problemshed (the temporal dimension of the problemshed whereby the impact of farming practices only play out after they are conducted is not represented in the graph).

\section{Conclusions}

A reflexive analysis of the participatory process we contributed to designing and implementing allowed identifying three conditions that we deem important for transdisciplinary research to support adaptive and innovative water governance. First, researchers from different backgrounds and disciplines should be able to overcome differences and share a common understanding of the objective and principles of the approach, if not of the tools to be used. This is not always easy, as transdisciplinary research projects tend to bring together strikingly different individuals. While this can be positive, significant attention needs to be paid to bringing all of the researchers together alongside the process. Second, tools and facilitation techniques ought to be designed and adapted in a way that allows for the expression of multiple and sometimes diverging viewpoints, which implies reducing (power) asymmetries to create new knowledge on how to deal with complex issues. This requires a highly adaptable and iterative way of conducting research that centers on "solving a problemshed". Focusing on a "problemshed" whose main characteristics are fleshed out during the transdisciplinary research process rather than using an entry point that stems from an international model (such as the watershed in IWRM in our case) is indeed the third, and maybe more important, dimension for transdisciplinary research to support innovative water governance practices. Let us now put these findings in a broader perspective: that of enhancing social learning on environmental management issues while operating in context characterized by power asymmetries. 
Environmental issues are characterized by a high degree of scientific uncertainty and a profound lack of agreement on values among stakeholders, which led some scholars to talk of "wicked problems" [35,36]; this notion is rather similar to the more bounded term we use: "problemshed". To confront such complex policy dilemmas, social learning has been shown to increase the knowledge of individuals through social interactions and processes within a social network and favor the acquisition of collective skills [37]. Collective experiential learning is particularly efficient for this [38,39]; however, when done through a participatory approach, it is rather time consuming-especially in the field of environmental management [40]. It notably requires developing "learning networks" [41] of stakeholders to create a cooperative decision-making environment in which trust, understanding, and mutual reliance develop over time. In these networks, the traditional relationships between researchers (as the sole provider of knowledge) and other actors (seen as the recipient of that knowledge) need to be rethought, especially as the (transdisciplinary) research process aims at supporting innovative water governance. As has been suggested by Ozawa [42], it is important that researchers are seen and position themselves as "stakeholders and participants", rather than as "an objective third party". This is what we tried to do, although there is no denying that researchers-together with the White Volta Basin Officer-still had the upper hand on designing the research approach that followed. This is largely because the project took place in a "development context", whereby community members seldom contribute to the framing of issues. We attempted to rebalance this by giving enough space to different actors so that they could contribute to framing the problemshed that they thought the participatory process could support.

Seeing "researchers as participants" has a direct corollary: the recognition that they contribute to shaping and influencing power relationships in a context whereby "engineered" cross-scale interactions might actually lead to reinforcing the authority of powerful stakeholders or of those who initiate the process, and undermining trust in the network, as shown by Adger et al. [43]. In the context in which we operated, and following what Barnaud and Van Paassen [44] advocated, this led us to adopt a "critical companion" posture, in which we strategically dealt with power asymmetries to avoid increasing pre-existing initial power imbalances. We made this posture and our objectives to give more room to community members in the design of environmental regulations explicit, right from the start of the project through our engagement with the WVBO.

Another way that we strategically engaged with power asymmetries is through different tools that were used as boundary objects to crystallize interactions and knowledge generation. Using easily accessible tools such as role-playing games [45] might be less adapted to engagement with policy-makers (who tend to discard them as being not "serious" enough-this is the impression we got from regional decision-makers) than with grassroots people. On the other hand, using conceptual designs (such as computerized agent-based models) with participants who did not receive any formal education may prove to be difficult. Beyond the risk of selecting inappropriate tools to support the participatory process, there is also the risk of remaining too generic and too abstract to trigger constructive engagement of participants concerned with "real-life" problems or, on the contrary, getting bogged down in specifics that do not allow for generating constructive discussion among individuals with diverse vantage points. There, the adaptive nature of the research team and approach and the identification of a practical yet encompassing "problemshed" become crucial. Then, the next issue becomes whether and how the "learning network" that has emerged as a "boundary organization" should be institutionalized without losing its adaptive character and its ability to address a problemshed whose boundaries (both spatial and thematic) are changing. This is particularly relevant as the IWRM approach adopted in Ghana is currently being revised, notably through the establishment of sub-basin committees allowing for some degree of vertical integration.

Author Contributions: The three first authors contributed equally to the project design and implementation with W.D. and J.-P.V. facilitating the different multi-stakeholder platform while C.L.P. coordinating the development of computer-based model. The three first authors contributed equally to the writing of the article. A.A. contributed to the framing of the study. 
Funding: This research was carried out through Integrated management of rainwater and small reservoirs for multiple uses in the Volta River Basin by the Challenge Program for Water and Food (CPWF). This project was funded by the European Commission (EC) and technical support from the International Fund for Agricultural Development (IFAD) (Grant Number: COFIN-ECG-70-IWMI). The authors are responsible for the design of the study, data collection and analysis, and interpretation of the data, and the decision to submit the article for publication.

Acknowledgments: The authors would like to thank Fred Kizito, Patrick D'Aquino, Beth Cullen, Olufunke Cofie, Liza Debevec, Karen Greenhough, Isaac Gumah, Kalie Lasiter, Katherine Snyder, Stephanie Stawicki, and Tamara Amina Sulemana who contributed in different ways to the design and implementation of the activities described in this paper. We also thank all the participants to the workshops in the communities of Widnaba, Zongoyiri, Binaba, Mognori, Bazua, Binduri, Nafkuliga, and Bansi, in the Bawku Municipal and Bawku West District Assemblies, and the representatives of the Upper East Region.

Conflicts of Interest: The authors declare no conflict of interest. The founding sponsors had no role in the design of the study; in the collection, analyses, or interpretation of data; in the writing of the manuscript, and in the decision to publish the results.

\section{References}

1. Conca, K. Governing Water: Contentious Transnational Politics and Global Institution Building; MIT Press: Cambridge, MA, USA, 2006; ISBN 0-262-53273-5.

2. GWP (Global Water Partnership). Integrated Water Resources Management; GWP: Stockholm, Sweden, 2000.

3. United Nations. UN-Water Status Report on the Application of Integrated Approaches to Water Resources Management; United Nations: New York, NY, USA, 2012.

4. Chéné, J.M. Introduction-Integrated water resources management: Theory versus practice. Nat. Resour. Forum 2009, 33, 2-5. [CrossRef]

5. Lubell, M.; Edelenbos, J. Integrated Water Resources Management: A Comparative Laboratory for Water Governance. Int. J. Water Gov. 2013, 1, 177-196. [CrossRef]

6. Blomquist, W.; Schlager, E. Political Pitfalls of Integrated Watershed Management. Soc. Nat. Resour. 2005, 18, 101-117. [CrossRef]

7. Warner, J.; Wester, P.; Bolding, A. Going with the flow: River basins as the natural units for water management? Water Policy 2008, 10, 121-138. [CrossRef]

8. Shah, T.; Van Koppen, B. Is India ripe for integrated water resources management. Econ. Polit. Wkly. 2006, $41,3413-3421$.

9. Lankford, B.; Hepworth, N. The cathedral and the bazaar: Monocentric and polycentric river basin management. Water Altern. 2010, 3, 82-101.

10. Bodin, O.; Crona, B. Management of Natural Resources at the Community Level: Exploring the Role of Social Capital and Leadership in a Rural Fishing Community. World Dev. 2008, 36, 2763-2779. [CrossRef]

11. Cooke, B.; Kothari, U. Participation: The New Tyranny; Zed Books: London, UK, 2001; ISBN 1856497941.

12. Peterson, N. Excluding to Include: (Non) participation in Mexican natural resource management. Agric. Hum. Values 2010, 28, 99-107. [CrossRef]

13. Larson, K.L.; Lach, D. Participants and non-participants of place-based groups: An assessment of attitudes and implications for public participation in water resource management. J. Environ. Manag. 2008, 88, 817-830. [CrossRef] [PubMed]

14. Steins, N.A.; Edwards, V.M. Platforms for collective action in multiple-use common-pool resources. Agric. Hum. Values J. Theor. Polit. 1999, 16, 241-255. [CrossRef]

15. Warner, J. The Beauty of the Beast: Multi-Stakeholder Participation for Integrated Catchment Management. In Multi-Stakeholder Platforms for Integrated Water Management; Warner, J., Ed.; Ashgate Publishing Ltd.: Hampshire, UK, 2007; pp. 1-19.

16. Faysse, N. Troubles on the way: An analysis of the challenges faced by multi-stakeholder platforms. Nat. Resour. Forum 2006, 30, 219-229. [CrossRef]

17. Kelly, R.A.; Jakeman, A.J.; Barreteau, O.; Borsuk, M.E.; ElSawah, S.; Hamilton, S.H.; Henriksen, H.J.; Kuikka, S.; Maier, H.R.; Rizzoli, A.E.; et al. Selecting among five common modelling approaches for integrated environmental assessment and management. Environ. Model. Softw. 2013, 47, 159-181. [CrossRef] 
18. Rossing, W.A.H.; Zander, P.; Josien, E.; Groot, J.C.J.; Meyer, B.C.; Knierim, A. Integrative modelling approaches for analysis of impact of multifunctional agriculture: A review for France, Germany and The Netherlands. Agric. Ecosyst. Environ. 2007, 120, 41-57. [CrossRef]

19. Zvoleff, A.; An, L. Analyzing human-landscape interactions: Tools that integrate. Environ. Manag. 2014, 53, 94-111. [CrossRef] [PubMed]

20. d'Aquino, P.; Bah, A. The multilevel participatory modelling of land use policies in African drylands: A method to embed adaptability skills of drylands societies in a policy framework. J. Environ. Manag. 2014, 132, 207-2019. [CrossRef] [PubMed]

21. Hare, M. Forms of participatory modelling and its potential for widespread adoption in the water sector. Environ. Policy Gov. 2011, 21, 386-402. [CrossRef]

22. Pahl-Wostl, C. A conceptual framework for analysing adaptive capacity and multi-level learning processes in resource governance regimes. Glob. Environ. Chang. 2009, 19, 354-365. [CrossRef]

23. Mostert, E. Participation for Sustainable Water Management. In Sustainable Management of Water Resources: An Integrated Approach; Giupponi, C., Jakeman, A., Karssenberg, D., Hare, M., Eds.; Elgar: Cheltenham, UK, 2006; pp. 153-172, ISBN 978-1-84-542745-0.

24. Mollinga, P.P.; Meinzen-Dick, R.S.; Merrey, D.J. Politics, plurality and problemsheds: A strategic approach for reform of agricultural water resources management. Dev. Policy Rev. 2007, 25, 699-719. [CrossRef]

25. Government of Ghana-Ministry of Water Resources Works and Housing. National Water Policy; Government of Ghana: Accra, Ghana, 2007.

26. Bawku Municipal Assembly. Medium Term Development Plan (2010-2013) 266; Bawku Municipal Assembly: Bawku, Ghana, 2009.

27. Bawku West District Assembly. Medium Term Development Plan (2010-2013) 239; Bawku West District Assembly: Bawku, Ghana, 2009.

28. Etienne, M. Companion Modelling: A Participatory Approach to Support Sustainable Development; Étienne, M., Ed.; Springer: Dordrecht, The Netherlands, 2014; ISBN 978-9-40-178556-3.

29. Van den Belt, M. Mediated Modeling: A System Dynamics Approach to Environmental Consensus Building; Island Press: Washington, DC, USA, 2004.

30. Barreteau, O.; Antona, M.; Aubert, S.; Boissau, S.; Bousquet, F.; Daré, W.; Etienne, M.; Le Page, C.; Mathevet, R.; Trébuil, G.; et al. Our Companion Modelling Approach. J. Artif. Soc. Soc. Simul. 2003, 6.

31. Sulemana, T.A. The Role of Traditional Authorities in Water Resource Management in Binaba, Bawku West District. Master Thesis, University for Development Studies, Tamale, Ghana, 2013.

32. Gumah, A.I. The Role of Public Institutions and Non-Governmental Organisations in Integrated Water Resources Management in the Bawku West District. Master Thesis, University for Development Studies, Tamale, Ghana, 2012.

33. Lasiter, K.; Stawicki, S. Linking Knowledge: A Qualitative Analysis of Gender and IWRM-related Policies in the Upper East Region of Ghana; CGIAR: Accra, Ghana, 2014.

34. Star, S.L.; Griesemer, J.R. Institutional Ecology, "Translations" and Boundary Objects: Amateurs and Professionals in Berkeley's Museum of Vertebrate Zoology, 1907-1939. Soc. Stud. Sci. 1989, 19, 387-420. [CrossRef]

35. Balint, P.J.; Stewart, R.E.; Desai, A.; Walters, L.C. Wicked Environmental Problems: Managing Uncertainty and Conflict; Island Press: Washington, DC, USA, 2011.

36. Van Bueren, E.M.; Klijn, E. Dealing with Wicked Problems in Networks: Analyzing an Environmental Debate from a Network Perspective. J. Public Adm. Res. Theory 2003, 13, 193-212. [CrossRef]

37. Reed, M.S.; Evely, A.C.; Cundill, G.; Fazey, I.; Glass, J.; Laing, A. What is Social Learning? Ecol. Soc. 2010, 15, r1. [CrossRef]

38. Armitage, D.R.; Plummer, R.; Berkes, F.; Arthur, R.I.; Charles, A.T.; Davidson-Hunt, I.J.; Diduck, A.P.; Doubleday, N.C.; Johnson, D.S.; Marschke, M.; et al. Adaptive co-management for social-ecological complexity. Front. Ecol. Environ. 2009, 7, 95-102. [CrossRef]

39. Kolb, D.A. Experiential Learning: Experience as the Source of Learning and Development; Prentice Hall: Englewood Cliffs, NJ, USA, 1984.

40. Barreteau, O.; Bots, P.; Daniell, K.; Etienne, M.; Perez, P.; Barnaud, C.; Bazile, D.; Becu, N.; Castella, J.-C.; Daré, W.; et al. Participatory approaches. In Simulating Social Complexity: A Handbook; Edmonds, B., Meyer, R., Eds.; Springer: Heidelberg, Germany, 2013; pp. 197-234. 
41. Stubbs, M.; Lemon, M. Learning to Network and Networking to Learn: Facilitating the Process of Adaptive Management in a Local Response to the UK's National Air Quality Strategy. Environ. Manag. 2001, 27, 321-334. [CrossRef] [PubMed]

42. Ozawa, C.P. Recasting Science. Consensual Procedures in Public Policy Making; Westview Press: Boulder, CO, USA, 1991; ISBN 081337961X.

43. Adger, W.N.; Brown, K.; Tompkins, E.L. The political economy of cross-scale networks in resource co-management. Ecol. Soc. 2005, 10. [CrossRef]

44. Barnaud, C.; Van Paassen, A. Equity, Power Games, and Legitimacy: Dilemmas of Participatory Natural Resource Management. Ecol. Soc. 2013, 18. [CrossRef]

45. Bousquet, F.; Barreteau, O.; D’Aquino, P.; Etienne, M.; Boissau, S.; Aubert, S.; Le Page, C.; Babin, D.; Castella, J.-C. Multi-agent systems and role games: Collective learning processes for ecosystem management. In Complexity and Ecosystem Management. The Theory and Practice of Multi-Agent Systems; Janssen, M.A., Ed.; Edward Elgar Publishing: Cheltenham, UK, 2002; pp. 248-285.

(C) 2018 by the authors. Licensee MDPI, Basel, Switzerland. This article is an open access article distributed under the terms and conditions of the Creative Commons Attribution (CC BY) license (http:/ / creativecommons.org/licenses/by/4.0/). 